\title{
Market Discipline and Bank Risk Taking: Evidence from the East Asian Banking Sector
}

\author{
Fazelina Sahul Hamid \\ School of Distance Education, Universiti Sains Malaysia \\ fazelina@usm.my \\ Norhanishah Mohd Yunus \\ School of Distance Education, Universiti Sains Malaysia \\ norhanishah@usm.my
}

\begin{abstract}
The third pillar of the Basel II highlights the role of market discipline in easing the existing pressure on traditional monitoring measures like capital requirement and government supervision. This study test the effectiveness of market discipline in inducing prudential risk management practices among the East Asian banks over the 1995 to 2005 period. Market discipline is measured using information disclosure and interbank deposit holdings. We find that only the latter is an effective market discipline tool. However, the former becomes effective when market concentration is higher. We find that government owned, foreign owned and recapilatised banks are subject to market disciplining when disclosure in taken account but the opposite is true when interbank deposits is taken into account. Finally, we find that banks that disclose more risk related information hold more capital against their non-performing loan. The implications of the findings are discussed.

Keywords: Market Discipline, Bank Risk Taking, Information Disclosure, Panel Data, East Asian Banks

JEL Classification: G21, G28, N25
\end{abstract}

\section{INTRODUCTION}

Regulation and supervision in banking is intended to protect retail depositors and avoid the substantial welfare costs associated with bank failures. Nevertheless, deriving optimal regulation in the banking industry is not an easy task due to the costs involved, political pressure or interest group pressure. In light of these considerations, market discipline is highlighted as one of the key areas of the reform policy in the banking sector. The recent financial crisis highlights the problems of moral hazard and asymmetric information which are rampant in the 
banking sector. In line with this, the reforms proposed in the Basel III require banks to provide a more relevant and timely information to the stakeholders that enable them to better assess banks' overall capital adequacy and risk profile. Greater disclosure not only improves prudential regulations but more importantly it facilitates effective market discipline. This shows that issues related to market discipline in banking sector are important and remain relevant in the era of Basel III.

Market discipline involves monitoring and influencing by investors (Bliss and Flannery, 2002). Monitoring refers to the investors' capability of assessing a firm's actual situation and sending market signals to the managers. However, it is a necessary but not sufficient condition for market discipline (Bliss, 2004). For market discipline to be effective, it must involve influencing. This happens when bank managers respond to investors' feedback that is reflected in their withdrawal actions or price movements by making more conservative decisions and safer investments (Goldberg and Hudgins, 2002). In this case, Greenspan (2001) asserts that market discipline acts as a 'private counter party supervision' in the banking sector that enables stakeholders to safeguard their interest against excessive risk taking by banks. This present study aims to analyze the effectiveness of market discipline in limiting banks' risk taking behavior. More specifically, it aims to find if market discipline provides banks with the incentive to hold adequate amount of capital as a cushion against potential future losses that may arise from their risk exposure.

Most of the empirical studies have tested the effectiveness of market discipline by focusing on the monitoring aspect. In the context of East Asia, studies by Hosono et al. (2005) and Hamid (2014) confirm that depositors discipline banks by withdrawing their funds from the weaker ones. Nevertheless, with the exception of Nier and Baumann (2006) and Wu and Bowe (2010), not many studies have empirically tested the ability of market discipline in influencing banks' risk taking behavior. The latter study is focused on China while the former is focused on developed countries. This paper complements the existing literature by carrying out similar analyses on the East Asian banks. The findings of this study can be used to identify whether market discipline tools are effective in encouraging greater prudence among bank managers. In addition, the findings can also identify under what circumstances market discipline becomes more effective. This will give us a better perspective about how the role of market discipline can 
be enhanced so that it can facilitate in reducing the social cost associated with bank supervision.

In this paper, we study the extent to which market discipline exists in the East Asian banking sector. This banking sector is chosen for a number of reasons. Firstly, banks have traditionally played a very important role in the East Asian economies. Banks in the region have undergone rapid liberalization, financial crisis and reform during the period studied. This study aims to examine whether the changes that have taken in the banking system have influenced banks' risk taking behavior. More specifically, given the fact that many bank failures happened during this period and large amounts of public funds were used to bail out weak banks (Hamid, 2013), this study aims to examine if market discipline was effective in influencing banks' risk taking behavior during this period. Secondly, the 1997 financial crisis had a very damaging effect on the East Asian banking sector. A large number of banks were insolvent and had to be recapitalized, merged or acquired or closed subsequently. This reduced the number of players in the industry. The banking system in East Asia became more concentrated as a result. In line with "too big to fail" theory, larger bank operations increase market power and encourage greater risk taking as evidenced in studies by De Nicoló et al. (2006). Thus, we examine whether greater market concentration has a negative effect on the effectiveness of market discipline.

Thirdly, government ownership of banks is prevalent in the East Asian banking system as highlighted in studies by Laeven and Levine (2009), Williams and Nguyen (2005) and Micco et al. (2007). The "political" theory links government ownership of institutions to inefficient allocation of resources allocation. Existing studies confirm that government ownership is associated to lower performance (La Porta et al., 2002), lower efficiency (Williams and Nguyen, 2005) and higher risk (Wu and Bowe, 2010). Given that government owned banks are more likely to be bailed out in the event of a financial distress compared to others, they may be less sensitive to external pressure. Hence, this study examines whether this is true in the case of the East Asian banking system. Lastly, foreign ownership of banks in East Asia has been linked to greater efficiency (Laeven, 1999), lower financial fragility (Arena, 2008; Hamid, 2013) and lower likelihood of crisis (Barth et al., 2004). Thus, we examine whether foreign owned banks are more sensitive to market based disciplinary mechanism. 
Overall, the results of this study confirm that information disclosure is an effective market discipline mechanism when market concentration is higher. However, interbank deposits lose their effectiveness when the market becomes more concentrated. We also find that disclosure is an effective market discipline tool for government owned banks, foreign banks and recapitalized banks but interbank deposits are not. Finally, we find that the effectiveness of information disclosure depends on the level of banks' loan quality.

This paper is organized as follows. Section II provides an overview of the literature review. Section III provides the model descriptions. The empirical results are discussed in Section IV. Section V concludes the paper.

\section{LITERATURE REVIEW}

Pillar 3 of Basel II emphasizes the role of market discipline as an additional tool that complements the minimum capital requirements and supervisory review process in promoting a safe and sound banking system. Market discipline can be signaled by all three groups of bank shareholders: depositors, debt holders and equity holders (Flannery, 2001). Stakeholders can discipline banks using a price-based approach and a quantity-based approach. Under the first approach stakeholders demand higher return as a compensation for high risk taking, while under the second approach stakeholder discipline risky banks by withdrawing their funds. ${ }^{1}$ As highlighted by Berger (1991), Flannery (2001) and Hamalainen et al. (2001), most of the earlier literature has been mainly focused on identifying whether stakeholders discipline banks using the two approaches. However, Bliss and Flannery (2002) assert the effectiveness of market discipline need to be assessed based on its ability in influencing banks' risk taking behavior. In line with this, studies by Cordella and Levy Yeyati (1998) and Blum (2002) show that the ability of market in inducing prudential behavior among bank mangers depends on the visibility of banks risk choices and the amount of uninsured deposits.

${ }^{1}$ Studies by Baer and Brewer (1986), Ellis and Flannery (1992), Cook and Spellman (1994) find that there is a positive relationship between the rate of large uninsured CDs of US banks, and the riskiness of the banks. On the other hand, studies by Goldberg and Hudgins (1996), Calomiris and Mason (1997), Martinez Peria and Schmukler (1999) find a positive relationship between banks' risk and deposit withdrawals.

(c) Korea Institute for International Economic Policy 
Information disclosure is a prerequisite for market discipline (Hamalainen et al., 2003). Stakeholders' ability to differentiate between good and bad banks will depend on the quantity and quality of information disclosed by banks. In line with this, Pillar 3 emphasizes on the role of information disclosure in strengthening market discipline. Theoretical models developed by Blum (2002), Boot and Schmeits (2000), Cordella and Levy Yeyati (1998) postulate that banks that voluntarily disclose more information about their risk exposure will select a lower default risk in equilibrium. Since more disclosure exposes banks to greater public scrutiny, stakeholders will demand higher compensation from risky banks as shown by Baer and Brewer (1986), Ellis and Flannery (1992) and Cook and Spellman (1994). As a result, banks need to ensure that their risk taking incentives are readjusted to other banks which do not disclose as much information. The effectiveness of disclosure in promoting a safer banking system is confirmed by Tadesse (2006). Using the data on 49 countries, this study finds that banking crises are less likely in countries with better disclosure.

Theoretical models developed by Diamond and Dybvig (1986) and Flannery (1994) assert that deposit insurance reduces depositors' incentive to monitor banks' risk taking. Hence, they postulate that market discipline is likely to be more effective when the amount of uninsured funding is larger for a given rise in bank risk. Goldberg and Hudgins (2002) analyzed the relationship between uninsured deposits and financial institutional failures in United States for the period from 1984 to 1994. They find that failed institutions have lower proportions of uninsured deposits-to-total-deposits before the failure and that failing institutions attract fewer deposits from uninsured depositors before the failure than do solvent institutions. This implies that the effectiveness of market discipline is linked to the amount of uninsured deposits. Existing studies by Gropp and Vesala (2004), Hoang et al. (2014) have also tested the proposed relationship and find that banks that have larger amount of uninsured funding take less risk.

A theoretical model developed by Cordella and Levy Yeyati (1998) and Blum (2002) asserts that banks' risk choices will be efficient in the event that bank deposits are not insured and the bank's risk choices are visible to the depositors. This happens because the banks incorporate the impact of their risk choice on depositors given that depositor will demand higher compensation from banks that incur higher risks. In line with this proposition, Nier and Baumann (2006) developed an empirical model to test the effectiveness of market discipline in 
reducing excessive risk taking behavior by banks that depends on the extent to which the bank is financed by uninsured liabilities and the observability of bank risk choices.

They used the model to test the effectiveness of market discipline in 32 developed countries. Wu and Bowe (2010) used a similar model for banks in China. They find a positive relationship between information disclosure and a bank's equity capital. In line with the proposition of signaling theory, their findings confirm that greater risk-related disclosure is associated with lower risk taking by bank managers. This suggests that safer banks are more transparent. In addition, both studies also find that banks that have larger amount of uninsured funding take less risk. Overall, their findings confirm that market discipline provides banks with an incentive to maintain a strong capital base as a cushion against potential future losses arising from their risk exposure.

This paper contributes towards existing literature by analyzing the effectiveness of market discipline in encouraging a more prudential risk taking behavior among bank managers in the East Asian banking sector. Using the model developed by Nier and Baumann (2006), this study will directly test the effect of market discipline on banks' risk taking behavior measured using the Basel criteria definition of total capital over risk-weighted assets. Given the consolidation that has taken place in the East Asian banking sector, this study will test if the effect of market discipline becomes weaker as a result of increased market concentration. The effectiveness of market discipline will also be tested by taking into account the ownership structure of the banks. Analysis on banks risk taking incentives is performed for the period from before crisis to after crisis (i.e. 1995 to 2005). The analyses will be carried out using panel data random effect model.

\section{METHODOLOGY}

This paper aims to analyze the effectiveness of market discipline in influencing banks' risk taking behavior. To empirically test this hypothesis, a model that represents a general relationship between bank capital, bank-specific variables, market discipline measures and country-specific variables is formulated following by Nier and Baumann (2006), Wu and Bowe (2010). The model is given as: 


$$
\begin{aligned}
& \text { Capital }_{\mathrm{i}, \mathrm{j}, \mathrm{t}}=\alpha_{0}+\beta_{1} \mathrm{ROA}_{\mathrm{i}, \mathrm{j}, \mathrm{t}}+\beta_{2} \mathrm{NPL}_{\mathrm{i}, \mathrm{j}, \mathrm{t}}+\beta_{3} \text { Size }_{\mathrm{i}, \mathrm{j}, \mathrm{t}}+\beta_{4} \text { Market Discipline }_{\mathrm{i}, \mathrm{j}, \mathrm{t}}+ \\
& \beta_{5} \text { Ownership }_{\mathrm{i}, \mathrm{j}, \mathrm{t}}+\beta_{6} \mathrm{GDP}_{\mathrm{j}, \mathrm{t}}+\beta_{7} \mathrm{GDP} \text { per Capita }_{\mathrm{j}, \mathrm{t}}+\beta_{8} \text { Concentration }_{\mathrm{j}, \mathrm{t}}+\varepsilon_{\mathrm{i}, \mathrm{j}, \mathrm{t}}
\end{aligned}
$$

(Equation 1)

such that $\mathrm{i}=1, \ldots, \mathrm{N} ; \mathrm{j}=1, \ldots, \mathrm{J} ;$ and $\mathrm{t}=1, \ldots, \mathrm{T}$. Capital is the dependent variable which is defined as the total capital ratio for individual bank $i$ at time $t$ in country $j . n$ is the number of banks in each country. $\mathrm{j}$ is the number of countries (i.e. 5 countries). $t$ is the number of observations per bank (i,t varies because the panel is unbalanced). $\varepsilon$ is the error term.

\section{Dependent Variable}

Capital buffer enables banks to avoid bankruptcy (Kim and Santomero, 1998; Diamond and Rajan, 2000). In line with this, the 1988 Basel Accord emphasizes on the management of capital as a tool to measure banks' insolvency risk. In the event of financial distress, banks with higher buffer can use the excess capital to cover for losses and overcome the difficulties in raising fresh capital (Fonseca and Gonzalez, 2010). Banks also hold excess capital in order not to incur the costs associated with market discipline (Flannery and Rangan, 2008; Nier and Baumann, 2006; Wu and Bowe, 2010). In line with studies by Aggarwal and Jacques (1998), Jacques and Nigro (1997), Nier and Baumann (2006), Wu and Bowe (2010), the ratio of bank capital to risk-weighted assets (RCWA) based on the Basel criteria is used as a measure of banks' capital.

\section{Market Discipline Variables}

Based on Nier and Baumann (2006), Wu and Bowe (2010), we used two bankspecific variables to measure the strength of market discipline.

i) Information Disclosure

Compared to banks that do not disclose risk-related information to the public, banks that do are likely to hold more capital in relation to their risky assets. Disclosure Index is one of the commonly used disclosure variables in the existing 
literature. ${ }^{2}$ Disclosure Index consists of the list of selected accounting information that can be disclosed in the company report (Marston and Shrives, 1991). More specifically, Hassan and Marston (2010) define the disclosure index as "a research instrument to measure the extent of information reported in a particular disclosure vehicle(s) by a particular entity(s) according to a list of selected items of information."

Disclosure Index is measured based on the measurement framework proposed by Erlend Nier from the Bank of England. The index for each bank is derived using the amount of information available in banks' annual report on fifteen core disclosure items as reported in the Fitch IBCA BankScope database. This disclosure index is constructed using the check box approach similar to the CIFAR (Center for International Financial Analysis Research) index, but it is constructed at the bank level. ${ }^{3}$ This index consists of sub-indices that represent 15 categories of disclosure related to interest-rate risk, credit risk, liquidity risk, market risk, and capital (see Appendix). These items are very compatible with the frameworks proposed by IMF's Financial Soundness Indicators (FSI) and Basel Committee (Huang, 2006). Studies by Nier and Baumann (2004), Huang (2006), Nier and Baumann (2006), Wu and Bowe (2010), Hamid (2014) have used this index. Based on the empirical framework proposed by Nier and Baumann (2006) and $\mathrm{Wu}$ and Bowe (2010), we posit that greater information disclosure should be positively related to a bank's equity capital in order for market discipline to be effective.

\section{ii) Interbank}

Existing literature suggests that market discipline is more effective when the amount of uninsured funding is higher. In line with studies by Enkhbold and Otgonshar (2013), Nier and Baumann (2006) and Wu and Bowe (2010), interbank deposits are used as a proxy for uninsured funding. This variable is measured by the ratio of bank deposits to total deposits. ${ }^{4}$ Since banks are exposed to similar

2 Marston and Shrives (1991) provides survey of the use of disclosure indices. Hassan and Marston (2010) provide the comprehensive survey of the use of various disclosure proxies.

3 CIFAR index consist of ninety items that are included in the companies' annual report. Seventy percent of the companies are involved in the non-financial sector.

${ }^{4}$ Interbank deposits is used as a variable to measure uninsured funding due to lack of data on subordinated debt for some East Asian countries. 
shocks to risks, banks are likely to be more informed investors in the interbank market. As a result, funding provided by banks is likely to be more sensitive to lenders risk exposure. In addition, interbank depositors also have more incentive in disciplining banks compared to other depositors because their deposits are not covered by the deposits insurance plans. Based on the theoretical and empirical framework proposed by Flannery (1994) and Sironi (2001), we predict that the effect of market discipline should be stronger when the amount of bank deposits is higher. Hence, we expect a positive relationship between interbank deposit and capital ratio.

\section{Bank Specific Variables}

Banks can either generate capital externally or internally. The latter is a cheaper source of funds compared to the former. Banks with higher profitability can generate more capital internally through retained earnings compared to less profitable banks. In this study, ROA is used as the measure of banks' ability to raise funds internally. It is measured as the pre-tax profits over total assets. Studies by Gropp and Heider (2009), Kleff and Weber (2008) find that profitable banks tend to have relatively more equity. NPL is defined as the ratio of nonperforming loans to total loans. It is a measurement of banks' credit risk. Higher ratio indicates that the banks have poor loan quality. Following studies by Ayuso et al. (2004), Nier and Baumann (2006), Wu and Bowe (2010), the size of the banks is controlled for. Size is measured as the natural logarithm of Total Assets. Larger banks are exposed to lower idiosyncratic risks due to greater diversification. As a result, they may have less incentive to hold high capital buffer against losses. On the other hand, smaller banks may find it difficult to obtain capital, and as result, may need to hold higher capital buffer.

\section{Country Specific Variables}

The level of capital is also influenced by economic growth (Borio et al., 2001). Banks make more profit when economic growth is high and this may contribute towards higher capital holdings. Studies by Asarkaya and Ozcan (2007), Nier and Baumann (2006), Wu and Bowe (2010) have used GDP growth to control for the business cycle. The movements of capital is procyclical as banks' capital increases 
during good times through retained earnings but decreases during bad times due to lower earnings and difficulties in raising fresh capital. ${ }^{5}$ However, a study by Jokipii and Milne (2008) finds a negative relationship between capital and business cycle. In line with these studies, we include GDP as a country-specific variable that measures the annual percentage growth rate of GDP. Since East Asian economies often show co-movement in their business cycles, we have included GDP per capita and country dummy as additional variables to control for country specific effect.

In line with Wu and Bowe (2010), we use Herfindahl-Hirschman Index (HHI) and four bank concentration ratio (CR4) as measures of banking sector concentration. $\mathrm{HHI}$ is defined as the sum of the squares of market shares of all the banks in a country, where the market shares are measured using total assets as a proxy for bank size. HHI gives higher weight to larger banks compared to the smaller ones. Higher $\mathrm{HHI}$ is associated with greater concentration in the banking industry while lower HHI is associated with greater competition in the industry. CR4 is measured using the total deposit of the four largest banks to the total deposits of all the banks in the sample for each country in a given year. CR4 will be equal to 1 in a pure monopolistic market and equal to 0 in a perfectly competitive market.

The banking sector restructuring that happened in East Asia as a result of the crisis has increased market concentration in the region (Williams and Nguyen, 2005). Hence, in this study we want to finds out how these changes influence the effectiveness of market discipline.

\section{Estimation Procedure}

The effectiveness of market discipline in the East Asian banking sector is measured using Equation 1. Further analyses are performed using Equation 2 to investigate the link between market discipline and market concentration. In doing so, two of the market concentration variables are introduced separately and the interaction term of market concentration and market discipline variables are included as a moderator in the following specification:

5 One of the reasons for this is the pro-cyclical nature of loan demand (Gambacorta and Mistrulli, 2004; Stolz and Wedow, 2011; Tabak et al., 2011).

(c) Korea Institute for International Economic Policy 


$$
\begin{aligned}
& \text { Capital }_{\mathrm{i}, \mathrm{j}, \mathrm{t}}=\alpha_{\mathrm{o}}+\beta_{1} \mathrm{ROA}_{\mathrm{i}, \mathrm{j}, \mathrm{t}}+\beta_{2} \mathrm{NPL}_{\mathrm{i}, \mathrm{j}, \mathrm{t}}+\beta_{3} \operatorname{Size}_{\mathrm{i}, \mathrm{j}, \mathrm{t}}+\beta_{4} \text { Market Discipline }_{\mathrm{i}, \mathrm{j}, \mathrm{t}}+ \\
& \beta_{5} \text { Ownership }_{\mathrm{ij}, \mathrm{t}}+\beta_{6} \mathrm{GDP}_{\mathrm{j}, \mathrm{t}}+\beta_{7} \mathrm{GDP} \text { per Capita } \mathrm{j}, \mathrm{t}+\beta_{8} \text { Concentration }_{\mathrm{j}, \mathrm{t}}+ \\
& \beta_{9} \text { Market Discipline }_{\mathrm{i}, \mathrm{j}, \mathrm{t}}{ }^{*} \text { Concentration }_{\mathrm{j}, \mathrm{t}}+\varepsilon_{\mathrm{i}, \mathrm{j}, \mathrm{t}}
\end{aligned}
$$

(Equation 2)

Based on the above equation, we expect a positive coefficient for $\beta_{4}$ and a negative coefficient for $\beta_{8}$. This would suggest that greater concentration reduces the effectiveness of market discipline.

Studies have also linked ownership structure with bank capital (Nier and Baumann, 2006; Schaeck and Cihak, 2007; Tabak et al., 2011; Wu and Bowe, 2010). State-owned banks are more likely to hold less capital buffer than private banks (Tabak et al., 2011). This happens because they are often politically-linked, and as a result it is easier for them to raise new capital. State-owned banks capital buffer is also found to be less sensitive to the level of risk (Wu and Bowe, 2010). In contrast, Bongini et al. (2001) find that foreign-owned banks practice a more sophisticated corporate governance system and as a result are more efficient in managing risk. Hence, they can be expected to hold higher capital buffers. We therefore incorporate two variables that capture government and foreign ownership. In addition, we take into account the banks' listing status in the stock exchange. Studies by Nier and Baumann (2006) and Wu and Bowe (2010) confirm that listed banks hold more capital. A number of banks in East Asia were recapitalized as part of the bank restructuring exercise. We also take this into account in our study.

Analyses are also performed by taking into account the effect of bank ownership on market discipline based on the following specification:

$$
\begin{aligned}
& \text { Capital }_{i, j, t}=\alpha_{0}+\beta_{1} \text { ROA }_{i, j, t}+\beta_{2} \text { NPL }_{i, j, t}+\beta_{3} \text { Size }_{\mathrm{i}, \mathrm{j}, \mathrm{t}}+\beta_{4} \text { Market Discipline }_{\mathrm{i}, \mathrm{j}, \mathrm{t}}+ \\
& \beta_{5} \text { Ownership }_{\mathrm{i}, \mathrm{t}, \mathrm{t}}+\beta_{6} \mathrm{GDP}_{\mathrm{j}, \mathrm{t}}+\beta_{7} \mathrm{GDP} \text { per Capita } \mathrm{j}, \mathrm{t}+\beta_{8} \text { Concentration }_{\mathrm{j}, \mathrm{t}}+ \\
& \beta_{9} \text { Market Discipline }_{\mathrm{i}, \mathrm{j}, \mathrm{t}}{ }^{*} \text { Ownership }_{\mathrm{i}, \mathrm{j}, \mathrm{t}}+\varepsilon_{\mathrm{i}, \mathrm{j}, \mathrm{t}}
\end{aligned}
$$

(Equation 3)

A diagnostic test on the residuals of the basic pooled Ordinary Least Square (OLS) regressions shows that the residuals are not normal. This implies that Generalized Least Square (GLS) procedure is preferable compared to OLS. Hence, the estimation is performed using random effect panel (GLS) models. Given that 
the bank ownership dummy variables do not exhibit substantial time-invariance, random effect model is preferred over the fixed-effect ones.

In analyzing the effectiveness of market discipline on a bank's prudential risk management decisions, there might still be an issue of some variables not being exogenous with respect to bank risk (i.e. they are correlated with the error terms). As argued by Nier and Baumann (2006) and Wu and Bowe (2010), banks' decision to raise more capital may influence their decision to disclose more risk-related information or engage in the inter-bank deposits market. For example, a bank that plans to raise more equity may need to disclose more information about their risk choices in order to attract capital. Estimations that are carried out without controlling for the potential endogeneity between the dependent and independent variables can be misleading.

Two-Stage Least Square (2SLS) analyses are performed in order to account for the possible endogeneity of the market discipline variables with respect to bank risk (i.e. they are correlated with the error terms). The instruments that are used in the analyses include ownership dummies, ROA, LogAsset, the loan to asset ratio defined as total loans to total assets, the cost to income ratio defined as overheads over net interest revenues plus operating incomes, and yearly time dummies. We have used the current year value for all the bank specific variables. While all of these variables are endogenous over longer horizons, they are unlikely to be controlled by the bank over a one-year period and are therefore taken as exogenous as suggested by Nier and Baumann (2006). Given that both of the market discipline variables exhibit time-varying characteristics, yearly time dummies are included in the first stage regressions.

\section{RESULTS}

\section{Data Description}

The analysis is performed using the sample of commercial banks in five East Asian countries namely Indonesia, Korea, Malaysia, Philippines and Thailand. Bank level data is obtained from BankScope. The database for each bank is obtained for the period from 1995 to 2005 . Country level macroeconomic data is obtained from the International Monetary Fund's International Financial Statistics database. Data on bank ownership and recapitalization in the five East Asian 
countries is obtained from BankScope, banks' and central banks' website. All commercial bank data that is available from BankScope are used for our analysis. This yielded an initial sample of 122 banks that have data on Capital Ratio. The number of observation available for the regression analysis changes according to the variables used in the regressions.

Table 1 shows the summary statistics of the bank specific, macroeconomic and market discipline variables. The dataset displays the overall, between and within variations of the variables. The results show that the within variations of the bank specific and market discipline variables for the aggregate banking system are lower compared to the between variations. ${ }^{6}$ This highlights the importance of analyzing the cross-sectional dimension of the data. The results also show that foreign owned banks hold higher capital on average. The between and overtime variations of the capital ratio are higher for the government owned banks compared to others. This suggests that there are noticeable differences in the level of capital holdings among the government owned banks and government owned banks have experienced significant structural changes to their capital ratio during the sample period. Foreign banks have higher ROA and NPL/Loans on average and higher variations in the two variables compared to other banks. Government owned banks and recapitalized banks are bigger in size. Moreover, time variation in size is noticeably lower compared to between variations in size for all categories of banks. This suggests that there are significant differences in the sizes of the banks. As far as the market discipline variables are concerned, we find that foreign banks have highest Interbank deposits on average compared to other banks while listed banks have lower Interbank deposits compared to other banks. In addition, variation in Interbank deposits between all categories of banks is higher compared to variations in time. Particularly, we find that government owned banks have approximately three times larger variation in Interbank deposits between banks compared to variation in Interbank deposits over time.

${ }^{6}$ Except for ROA which has higher within variation. 
Table 1. Summary Statistics

\begin{tabular}{|c|c|c|c|c|c|c|c|}
\hline Variable & Obs & Mean & Std & $\begin{array}{c}\text { Between } \\
\text { Std } \\
\end{array}$ & $\begin{array}{c}\text { Within } \\
\text { Std }\end{array}$ & Min & Max \\
\hline \multicolumn{8}{|c|}{ Bank Specific Variables } \\
\hline Capital Ratio & 831 & 19.43 & 24.53 & 18.85 & 14.80 & -236.20 & 296.70 \\
\hline Gov. Owned & 125 & 18.65 & 44.75 & 34.77 & 26.23 & -236.20 & 296.70 \\
\hline Foreign Owned & 219 & 26.15 & 25.08 & 18.82 & 16.79 & -43.70 & 190.01 \\
\hline Listed & 390 & 13.61 & 16.13 & 8.54 & 13.80 & -236.20 & 65.69 \\
\hline Recapitalised & 68 & 12.43 & 9.47 & 2.17 & 9.26 & -47.40 & 33.20 \\
\hline ROA & 1639 & 0.30 & 7.37 & 2.62 & 6.90 & -112.21 & 119.99 \\
\hline Gov. Owned & 227 & -0.31 & 6.20 & 2.34 & 5.67 & -70.56 & 7.72 \\
\hline Foreign Owned & 358 & 1.05 & 8.85 & 15.72 & 12.95 & -94.99 & 71.32 \\
\hline Listed & 803 & -0.35 & 7.08 & 2.89 & 6.54 & -112.21 & 28.16 \\
\hline Recapitalised & 108 & -0.32 & 4.88 & 1.59 & 4.64 & -40.20 & 8.84 \\
\hline NPL/Loans & 692 & 12.58 & 14.32 & 11.28 & 10.18 & 0.10 & 90.00 \\
\hline Gov. Owned & 99 & 11.85 & 8.67 & 6.97 & 5.39 & 0.40 & 37.70 \\
\hline Foreign Owned & 213 & 15.19 & 18.19 & 15.72 & 12.95 & 0.10 & 90.00 \\
\hline Listed & 296 & 11.44 & 13.40 & 9.83 & 9.81 & 0.20 & 81.40 \\
\hline Recapitalised & 47 & 15.29 & 15.11 & 7.64 & 13.53 & 1.20 & 72.40 \\
\hline Log Assets & 1638 & 14.11 & 1.95 & 1.89 & 0.41 & 9.27 & 9.01 \\
\hline Gov. Owned & 227 & 15.58 & 1.38 & 1.39 & 0.36 & 12.27 & 18.27 \\
\hline Foreign Owned & 358 & 13.01 & 1.35 & 1.29 & 0.44 & 10.19 & 16.12 \\
\hline Listed & 803 & 14.85 & 1.91 & 1.88 & 0.41 & 9.92 & 19.01 \\
\hline Recapitalised & 108 & 15.80 & 1.37 & 1.38 & 0.36 & 13.04 & 18.69 \\
\hline \multicolumn{8}{|c|}{ Macroeconomic Variables } \\
\hline GDP Growth & 1639 & 4.47 & 4.62 & 0.78 & 4.56 & -13.13 & 10.00 \\
\hline GDP Per Capita & 1639 & 3004.31 & 3649.10 & 3350.34 & 1464.04 & 3.01 & 13303.82 \\
\hline CR4 & 1639 & 55.79 & 9.79 & 6.26 & 7.54 & 30.24 & 77.51 \\
\hline$\underline{\mathrm{HHI}}$ & 1639 & 0.13 & 0.06 & 0.03 & 0.05 & 0.05 & 0.36 \\
\hline \multicolumn{8}{|c|}{ Market Discipline Variables } \\
\hline Information & 1327 & 11.57 & 2.19 & 1.95 & 1.32 & 4.00 & 17.00 \\
\hline Gov. Owned & 187 & 11.86 & 2.30 & 1.87 & 1.55 & 4.00 & 17.00 \\
\hline Foreign Owned & 337 & 11.39 & 1.98 & 1.52 & 1.25 & 5.00 & 15.00 \\
\hline Listed & 612 & 11.85 & 2.37 & 2.16 & 1.50 & 4.00 & 17.00 \\
\hline Recapitalised & 99 & 12.30 & 1.95 & 1.05 & 1.68 & 7.00 & 15.00 \\
\hline Interbank Deposits & 1061 & 13.95 & 18.92 & 18.54 & 9.50 & 0.00 & 100.00 \\
\hline Gov. Owned & 152 & 12.89 & 15.07 & 19.95 & 5.78 & 0.00 & 100.00 \\
\hline Foreign Owned & 235 & 27.27 & 25.24 & 22.65 & 13.84 & 0.00 & 97.40 \\
\hline Listed & 531 & 7.52 & 10.84 & 12.20 & 7.53 & 0.00 & 91.82 \\
\hline Recapitalised & 86 & 7.86 & 12.23 & 10.82 & 7.96 & 0.00 & 51.34 \\
\hline
\end{tabular}




\section{Empirical Findings}

The results in Table 2 show that ROA has a positive and significant effect on bank capital. This suggests that profitable banks hold more capital. The results show that there is no significant relationship between NPL and capital ratio. ${ }^{7}$ The coefficients on Log Assets are negative and significant in all specifications. This confirms that bigger banks hold less capital. This finding is in line with Nier and Baumann (2006), Wu and Bowe (2010). Both CR4 and HERF do not have significant relationship with bank capital. ${ }^{8}$ This evidence indicates that bank capital buffers are not sensitive to competition in the banking sector. Moreover, we also find that GDP growth have significant and positive effect on bank capital holdings in specifications 1 and 3, while GDP per capita have significant and positive effect on bank capital holdings in specifications 1,2 and 5. These suggest that banks hold more capital when economic growth and income are higher.

The effectiveness of market discipline is analyzed using two variables; Information and Interbank deposits. Banks that disclose more risk related information invite public scrutiny. Hence, they should realign their risk taking incentive to other banks that do not disclose similar information by holding more capital as a buffer against risky assets. However, results in Table 3 show that banks which publicly disclose more accounting information maintain a significantly lower capital ratio. This suggests that disclosure does not induce East Asian banks to take lower risks. The ability of a bank to obtain funding from the interbank market in a way reflects how other banks perceive its risk profile. Since bank deposits are not insured and banks are more informed about the risk profiles of other banks, a bank with higher interbank deposits may need to hold higher capital as compensation. The results in column 3 and 4 confirm that banks that borrow more from the interbank market maintain a significantly higher capital ratio. This confirms the effectiveness of interbank deposits as a market discipline tool. The findings also show that foreign banks hold lower capital while listed banks hold higher capital.

\footnotetext{
7 The positive effect on capital is only significant in specifications 1 .

8 Only CR4 is significant in specifications 1.
} 
Table 2. A Basic Model on Bank Capital

\begin{tabular}{|c|c|c|c|c|c|c|}
\hline & $(1)$ & (2) & (3) & (4) & (5) & (6) \\
\hline \multirow{2}{*}{ ROA } & $1.354^{* * * *}$ & $1.037^{* * *}$ & $0.954^{* * *}$ & $1.075^{* * *}$ & $1.050^{* * * *}$ & $1.099^{* * *}$ \\
\hline & $(0.213)$ & $(0.188)$ & $(0.321)$ & $(0.196)$ & (0.198) & $(0.206)$ \\
\hline \multirow{2}{*}{ NPL/Loans } & $0.311^{* *}$ & 0.0629 & 0.189 & -0.0123 & 0.0741 & 0.00949 \\
\hline & $(0.145)$ & $(0.203)$ & $(0.175)$ & $(0.208)$ & $(0.198)$ & $(0.201)$ \\
\hline \multirow{2}{*}{ Log Assets } & $-5.098^{* * *}$ & $-5.645^{* * *}$ & $-3.007^{* * *}$ & $-21.01^{* * *}$ & $-5.665^{* * *}$ & $-21.09^{* * * *}$ \\
\hline & $(0.750)$ & (1.657) & $(0.983)$ & $(6.305)$ & $(1.656)$ & $(6.284)$ \\
\hline \multirow{2}{*}{ CR4 } & $-0.341^{* *}$ & -0.140 & -0.184 & -0.107 & & \\
\hline & $(0.134)$ & $(0.215)$ & $(0.282)$ & $(0.226)$ & & \\
\hline \multirow{2}{*}{ HHI } & & & & & -22.98 & -26.47 \\
\hline & & & & & (32.35) & (33.44) \\
\hline \multirow{2}{*}{ GDP Growth } & $0.238^{*}$ & 0.0724 & $1.258^{*}$ & 0.142 & 0.0649 & 0.154 \\
\hline & $(0.145)$ & $(0.136)$ & $(0.741)$ & $(0.162)$ & (0.118) & $(0.144)$ \\
\hline \multirow{2}{*}{ GDP Per Capita } & $0.001^{* * *}$ & $0.000^{*}$ & -0.000 & 0.000 & $0.000^{*}$ & 0.000 \\
\hline & $(0.000)$ & $(0.000)$ & $(0.001)$ & $(0.000)$ & (0.000) & $(0.000)$ \\
\hline \multirow{2}{*}{ Country Dummy } & -0.0617 & 0.292 & -2.063 & & 0.143 & \\
\hline & $(0.659)$ & (1.106) & (1.609) & & (1.193) & \\
\hline \multirow{2}{*}{ Year } & $1.637^{* * *}$ & $1.704^{* * * *}$ & 0.974 & $3.191^{* * * *}$ & $1.656^{* * *}$ & $3.118^{* * * *}$ \\
\hline & $(0.368)$ & $(0.611)$ & $(0.825)$ & $(0.952)$ & $(0.575)$ & (0.909) \\
\hline \multirow{2}{*}{ Constant } & $-3,170^{* * *}$ & $-3,307^{* * *}$ & $-1,878$ & $-6,060^{* * * *}$ & $-3,214^{* * * *}$ & $-5,914^{* * *}$ \\
\hline & $(722.1)$ & $(1,195)$ & $(1,645)$ & $(1,814)$ & $(1,130)$ & $(1,734)$ \\
\hline $\begin{array}{l}\text { Type of } \\
\text { Estimation }\end{array}$ & OLS & $\begin{array}{l}\text { Random } \\
\text { Effect }\end{array}$ & $\begin{array}{c}\text { Between } \\
\text { Effect }\end{array}$ & $\begin{array}{l}\text { Fixed } \\
\text { Effect }\end{array}$ & $\begin{array}{l}\text { Random } \\
\text { Effect }\end{array}$ & $\begin{array}{l}\text { Fixed } \\
\text { Effect }\end{array}$ \\
\hline Observations & 536 & 536 & 536 & 536 & 536 & 536 \\
\hline Banks & & 122 & 122 & 122 & 122 & 122 \\
\hline R-squared & 0.304 & & 0.281 & 0.300 & & 0.304 \\
\hline
\end{tabular}

Robust standard errors in parentheses and ${ }^{* * *} \mathrm{p}<0.01,{ }^{* *} \mathrm{p}<0.05,{ }^{*} \mathrm{p}<0.1$ 
Table 3. The Effect of Market Discipline on Bank Capital

\begin{tabular}{|c|c|c|c|c|}
\hline & $(1)$ & $(2)$ & (3) & (4) \\
\hline \multirow{2}{*}{ Information } & $-38.43^{* *}$ & $-33.63^{* *}$ & & \\
\hline & $(15.94)$ & $(14.20)$ & & \\
\hline \multirow{2}{*}{ Interbank Deposits } & & & $2.596^{* * *}$ & $2.442^{* * *}$ \\
\hline & & & $(0.789)$ & $(0.684)$ \\
\hline \multirow{2}{*}{ CR4 } & 0.214 & & 0.703 & \\
\hline & $(0.489)$ & & $(0.517)$ & \\
\hline \multirow{2}{*}{ HHI } & & -83.96 & & 33.10 \\
\hline & & $(58.90)$ & & (53.79) \\
\hline \multirow{2}{*}{ ROA } & $1.382^{* *}$ & $1.345^{* * *}$ & $3.109^{* * *}$ & $3.164^{* * * *}$ \\
\hline & $(0.565)$ & $(0.497)$ & $(0.694)$ & $(0.646)$ \\
\hline \multirow{2}{*}{ NPL/Loans } & -0.175 & -0.0769 & $0.355^{*}$ & $0.420^{* * *}$ \\
\hline & $(0.256)$ & $(0.215)$ & $(0.194)$ & $(0.187)$ \\
\hline \multirow{2}{*}{ Log Assets } & -0.355 & -2.049 & $-5.728^{* * * *}$ & $-5.389^{* * * *}$ \\
\hline & $(3.140)$ & $(2.634)$ & $(1.920)$ & $(1.704)$ \\
\hline \multirow{2}{*}{ Government Owned } & 12.35 & 13.88 & -1.151 & -1.145 \\
\hline & $(10.46)$ & $(10.10)$ & $(7.944)$ & $(6.777)$ \\
\hline \multirow{2}{*}{ Foreign Owned } & 15.68 & 14.25 & $-27.65^{* *}$ & $-25.83^{* * *}$ \\
\hline & $(10.42)$ & $(9.872)$ & (12.02) & (10.43) \\
\hline \multirow{2}{*}{ Listed } & $27.63^{*}$ & $28.46^{*}$ & $22.32^{* *}$ & $22.71^{* * * *}$ \\
\hline & $(14.74)$ & $(14.72)$ & $(9.024)$ & $(8.010)$ \\
\hline \multirow{2}{*}{ Recapitalised } & 21.36 & 19.66 & 4.570 & 5.275 \\
\hline & $(14.71)$ & $(13.90)$ & (8.996) & (7.834) \\
\hline \multirow{2}{*}{ GDP Growth } & -0.518 & -0.252 & -0.267 & -0.0407 \\
\hline & $(0.576)$ & $(0.452)$ & $(0.427)$ & $(0.386)$ \\
\hline \multirow{2}{*}{ GDP Per Capita } & 0.001 & 0.000 & $0.002^{* *}$ & $0.002^{*}$ \\
\hline & $(0.001)$ & $(0.001)$ & $(0.001)$ & $(0.001)$ \\
\hline \multirow{2}{*}{ Country Dummy } & $8.372^{*}$ & 4.435 & -0.235 & -2.114 \\
\hline & $(4.576)$ & $(3.452)$ & $(2.540)$ & (2.293) \\
\hline \multirow{2}{*}{ Year } & $5.116^{* * * *}$ & $4.435^{* * *}$ & $2.085^{* * * *}$ & $1.972^{* * * *}$ \\
\hline & $(1.632)$ & $(1.372)$ & $(0.692)$ & $(0.676)$ \\
\hline \multirow{2}{*}{ Constant } & $-9,767^{* * * *}$ & $-8,411^{* * *}$ & $-4,159^{* * * *}$ & $-3,895^{\text {**** }}$ \\
\hline & $(3,133)$ & $(2,617)$ & $(1,385)$ & $(1,351)$ \\
\hline Observations & 513 & 513 & 443 & 443 \\
\hline Banks & 117 & 117 & 102 & 102 \\
\hline Goodness of Fit & 0.137 & 0.144 & 0.153 & 0.158 \\
\hline Wald chi (2) & $21.24^{* *}$ & $24.65^{* *}$ & $43.56^{* * *}$ & $51.96^{* * * *}$ \\
\hline
\end{tabular}

Standard errors in parentheses and ${ }^{* * *} \mathrm{p}<0.01,{ }^{* *} \mathrm{p}<0.05,{ }^{*} \mathrm{p}<0.1$ 
Major consolidation that took place on the East Asian banking sector after the crisis increased the market concentration in the banking sector. Based on Wu and Bowe (2010), we postulate that banks' incentives to hold more capital in relation to their risk weighted assets will be mediated by the degree of competition in the banking sector. In doing so, we include the interactive term of two concentration ratios with two market discipline variables; Information and Interbank. Table 4 presents the results. The interaction terms of Disclosure and concentration variables are shown to be positive and significant. This evidence suggests that disclosure becomes an effective market discipline tool when the banking sector becomes more concentrated. This could be due to fact that the consolidations that happened in East Asia removed weaker banks from the banking sector (Ito and Hashimoto, 2007). This suggests that disclosure becomes an effective market disciplining tool when there are stronger players in the banking system. In contrast, $\mathrm{Wu}$ and Bowe (2010) find that disclosure is linked lower capital holdings when market concentration increases. This could be due to the fact that greater market concentration in China is linked to increase in the government ownership of banks.

On the other hand, in line with Wu and Bowe (2010) the results in column 3 and 4 of Table 4 suggest that the net effect of Interbank deposits on capital becomes negative when the market becomes more concentrated. Since greater market concentration is linked with fewer players in the banking sector, banks will have lesser options to place their deposits. Our findings suggest that the collusive behavior of banks in a concentrated banking system could be the reason why Interbank deposits fail to be an effective market discipline tool.

The findings also show that greater concentration in the banking sector as measured by both the ratios is linked to lower capital holdings when disclosure and the interaction term of disclosure and market concentration are included in the model. However, both of the market concentration variables are linked to higher capital holdings when interbank deposits and the interaction term of interbank deposits and market concentration are controlled for. This suggests that the effects of concentration variables on capital holdings are sensitive to the type of market discipline variables used. 
Table 4. Market Concentration and Market Discipline

\begin{tabular}{|c|c|c|c|c|}
\hline & $(1)$ & $(2)$ & (3) & $(4)$ \\
\hline Information & $\begin{array}{c}-137.4^{* * * *} \\
(39.71)\end{array}$ & $\begin{array}{c}-62.79^{* * * *} \\
(16.02)\end{array}$ & & \\
\hline Information *CR4 & $\begin{array}{c}2.434^{* * *} \\
(0.699) \\
\end{array}$ & & & \\
\hline Information *HHI & & $\begin{array}{c}443.0^{* * *} \\
(110.1)\end{array}$ & & \\
\hline Interbank Deposits & & & $\begin{array}{c}7.840^{* * * *} \\
(1.456) \\
\end{array}$ & $\begin{array}{c}2.576^{* * * *} \\
(0.430)\end{array}$ \\
\hline Interbank Deposits *CR4 & & & $\begin{array}{c}-0.135^{* * *} \\
(0.026)\end{array}$ & \\
\hline Interbank Deposits ${ }^{*} \mathrm{HHI}$ & & & & $\begin{array}{c}-14.45^{* * *} \\
(2.505)\end{array}$ \\
\hline CR4 & $\begin{array}{c}-29.31^{* * * *} \\
(8.364)\end{array}$ & & $\begin{array}{l}1.689^{* * * *} \\
(0.443)\end{array}$ & \\
\hline HHI & & $\begin{array}{c}-5,227^{* * *} \\
(1,293)\end{array}$ & & $\begin{array}{l}157.6^{* * * *} \\
(45.19)\end{array}$ \\
\hline ROA & $\begin{array}{l}1.437^{* * *} \\
(0.297)\end{array}$ & $\begin{array}{l}1.421^{* * * *} \\
(0.338)\end{array}$ & $\begin{array}{l}1.987^{* * *} \\
(0.280)\end{array}$ & $\begin{array}{c}2.209^{* * * *} \\
(0.288)\end{array}$ \\
\hline NPL/Loans & $\begin{array}{c}0.449^{* * * *} \\
(0.160) \\
\end{array}$ & $\begin{array}{c}0.488^{* * * *} \\
(0.170) \\
\end{array}$ & $\begin{array}{c}0.347^{* * * *} \\
(0.114) \\
\end{array}$ & $\begin{array}{c}0.358^{* * * *} \\
(0.110) \\
\end{array}$ \\
\hline Log Assets & $\begin{array}{c}-6.017^{* * *} \\
(2.139)\end{array}$ & $\begin{array}{l}-1.220 \\
(3.198) \\
\end{array}$ & $\begin{array}{c}-6.300^{* * * *} \\
(1.260)\end{array}$ & $\begin{array}{c}-7.023^{* * * *} \\
(1.250) \\
\end{array}$ \\
\hline Government Owned & $\begin{array}{c}6.847 \\
(11.07) \\
\end{array}$ & $\begin{array}{c}6.015 \\
(13.95) \\
\end{array}$ & $\begin{array}{l}11.19^{* * *} \\
(5.299) \\
\end{array}$ & $\begin{array}{c}10.26^{*} \\
(5.411) \\
\end{array}$ \\
\hline Foreign Owned & $\begin{array}{l}0.0220 \\
(10.05) \\
\end{array}$ & $\begin{array}{c}5.936 \\
(12.64)\end{array}$ & $\begin{array}{l}-1.187 \\
(4.951)\end{array}$ & $\begin{array}{l}-5.655 \\
(5.253)\end{array}$ \\
\hline Listed & $\begin{array}{c}-8.365 \\
(9.536) \\
\end{array}$ & $\begin{array}{c}-2.992 \\
(11.32) \\
\end{array}$ & $\begin{array}{c}2.514 \\
(4.757) \\
\end{array}$ & $\begin{array}{c}9.319^{*} \\
(4.790) \\
\end{array}$ \\
\hline Recapitalised & $\begin{array}{l}-2.616 \\
(12.89) \\
\end{array}$ & $\begin{array}{c}-2.593 \\
(16.26) \\
\end{array}$ & $\begin{array}{l}-0.395 \\
(6.260) \\
\end{array}$ & $\begin{array}{c}2.142 \\
(6.367)\end{array}$ \\
\hline GDP Growth & $\begin{array}{l}-0.710^{* * *} \\
(0.334)\end{array}$ & $\begin{array}{c}-0.656^{* *} \\
(0.322)\end{array}$ & $\begin{array}{c}0.154 \\
(0.224)\end{array}$ & $\begin{array}{l}0.0347 \\
(0.200)\end{array}$ \\
\hline GDP Per Capita & $\begin{array}{l}-0.000 \\
(0.001)\end{array}$ & $\begin{array}{c}0.000 \\
(0.001)\end{array}$ & $\begin{array}{c}0.001 \\
(0.001)\end{array}$ & $\begin{array}{l}0.001^{* *} \\
(0.001)\end{array}$ \\
\hline Country Dummy & $\begin{array}{l}8.666^{\text {** }} \\
(3.532)\end{array}$ & $\begin{array}{l}12.36^{* * * *} \\
(4.487)\end{array}$ & $\begin{array}{c}1.777 \\
(1.701)\end{array}$ & $\begin{array}{c}0.665 \\
(1.655)\end{array}$ \\
\hline Year & $\begin{array}{c}2.549^{* * * *} \\
(0.483)\end{array}$ & $\begin{array}{l}2.880^{* * * *} \\
(0.589)\end{array}$ & $\begin{array}{l}1.637^{* * * *} \\
(0.403)\end{array}$ & $\begin{array}{l}1.602^{* * * *} \\
(0.390)\end{array}$ \\
\hline Constant & $\begin{array}{c}-3,364^{* * * *} \\
(906.1)\end{array}$ & $\begin{array}{c}-5,013^{* * * *} \\
(1,114)\end{array}$ & $\begin{array}{c}-3,284^{* * * *} \\
(800.2)\end{array}$ & $\begin{array}{c}-3,134^{* * * *} \\
(776.5)\end{array}$ \\
\hline Observations & 513 & 513 & 443 & 443 \\
\hline Banks & 117 & 117 & 102 & 102 \\
\hline Goodness of Fit & 0.115 & 0.153 & 0.176 & 0.212 \\
\hline Wald chi (2) & $64.72^{* * *}$ & $56.19^{* * *}$ & $123.38^{* * *}$ & $131.85^{\text {*** }}$ \\
\hline
\end{tabular}

Standard errors in parentheses and ${ }^{* * *} \mathrm{p}<0.01,{ }^{* *} \mathrm{p}<0.05,{ }^{*} \mathrm{p}<0.1$ 
Further analyses are carried out to identify the effect of market discipline upon four distinct groups of banks, namely foreign owned, government owned, listed and recapitalized. The foreign owned banks are controlled by foreign shareholders while the government owned banks are controlled by the government. Listed banks are publicly quoted on a stock exchange. Recapitalized banks are the ones that have received one or more injections of capital. The results in Table 5 show that government owned banks, foreign banks and recapitalized banks hold significantly lower capital. On the contrary, listed banks hold significantly higher capital. We find that the interaction term between Information and ownership variables are positive and significant. This suggests that government owned, foreign owned and recapitalized banks are able to raise capital by disclosing more risk related information to public. Listed banks are under greater public scrutiny as they are required to disclose risk related information to public on a more regularly basis compared to other banks. However, results in column 3 show that greater disclosure by listed banks is linked to lower capital holdings. This implies that disclosure is not an effective market discipline tool for listed banks as observed by Wu and Bowe (2010).

Banks' ability to attract interbank deposits partly reflects how their risk profiles are perceived externally. Hence, banks that regularly seek funding in the interbank market are expected to hold higher capital. Results in columns 5 to 8 of Table 5 confirm that banks that rely more on the interbank market do indeed hold higher capital. However, the operation of any disciplining effect is not evident for government owned, foreign owned and recapitalized banks. Column 7 indicates that Listed"Interbank is negative and significant, suggesting that listed banks that borrow more funds from the interbank market hold a lower level of capital. This could be due to fact that they are more reliant on equity funding compared to wholesale funding from the interbank market.

Non-performing loans ratio indicates the quality of banks' loan portfolio. Similar to Wu and Bowe (2010), we test the effectiveness of market discipline in improving banks prudential behavior for a given quality of loan portfolio. Greater disclosure of risk related information exposes banks to greater scrutiny and more disciplining action by stakeholder. For a given loan portfolio, we identify whether greater risk related disclosure induces banks to hold more capital. This is done by including the interaction term of Information and NPL ratio. Results in Table 6 show that the coefficient on non-performing loans ratio is negative and significant 
for all specifications. This indicates that banks with poor loan quality hold lower capital. The coefficients of the interaction terms of Information and NPL ratio are significant and positive. This confirms that banks that disclose more risk related information hold more risk-weighted capital for a given quality of loans.

Table 5. Ownership Structures and Market Discipline

\begin{tabular}{|c|c|c|c|c|c|c|c|c|}
\hline & (1) & $(2)$ & (3) & (4) & (5) & (6) & (7) & $(8)$ \\
\hline \multirow{2}{*}{ Information } & $-15.41^{* * *}$ & $-17.20^{* * *}$ & $35.35^{*}$ & $-15.06^{* * *}$ & & & & \\
\hline & $(5.820)$ & $(4.561)$ & $(20.13)$ & $(4.886)$ & & & & \\
\hline \multirow{2}{*}{$\begin{array}{l}\text { Information* } \\
\text { Gov. Owned }\end{array}$} & $11.95^{* *}$ & & & & & & & \\
\hline & $(5.761)$ & & & & & & & \\
\hline \multirow{2}{*}{$\begin{array}{l}\text { Information* } \\
\text { For. Owned }\end{array}$} & & $20.70^{* * * *}$ & & & & & & \\
\hline & & $(4.862)$ & & & & & & \\
\hline \multirow{2}{*}{$\begin{array}{l}\text { Information* } \\
\text { Listed }\end{array}$} & & & $-34.79^{*}$ & & & & & \\
\hline & & & $(20.18)$ & & & & & \\
\hline \multirow{2}{*}{$\begin{array}{l}\text { Information* } \\
\text { Recaplitalised }\end{array}$} & & & & $12.26^{* *}$ & & & & \\
\hline & & & & $(5.691)$ & & & & \\
\hline \multirow{2}{*}{ Interbank Deposits } & & & & & $0.475^{* * * *}$ & 0.0650 & $0.943^{* * *}$ & $0.504^{* * *}$ \\
\hline & & & & & $(0.090)$ & $(0.234)$ & $(0.150)$ & $(0.0921)$ \\
\hline \multirow{2}{*}{$\begin{array}{l}\text { Interbank Dep.* } \\
\text { Gov. Owned }\end{array}$} & & & & & 0.152 & & & \\
\hline & & & & & $(0.165)$ & & & \\
\hline \multirow{2}{*}{$\begin{array}{l}\text { Interbank Dep.* } \\
\text { For. Owned }\end{array}$} & & & & & & 0.174 & & \\
\hline & & & & & & $(0.242)$ & & \\
\hline \multirow{2}{*}{$\begin{array}{l}\text { Interbank Dep.* } \\
\text { Listed }\end{array}$} & & & & & & & $-0.626^{* *}$ & \\
\hline & & & & & & & $(0.248)$ & \\
\hline \multirow{2}{*}{$\begin{array}{l}\text { Interbank Dep.* } \\
\text { Recapilatised }\end{array}$} & & & & & & & & -0.391 \\
\hline & & & & & & & & $(0.287)$ \\
\hline \multirow{2}{*}{ ROA } & $1.127^{* * * *}$ & $1.208^{* * *}$ & 0.775 & $1.138^{* * *}$ & $1.948^{* * * *}$ & $1.799^{* * * *}$ & $2.357^{* * * *}$ & $1.959^{* * *}$ \\
\hline & $(0.265)$ & $(0.257)$ & $(0.596)$ & $(0.267)$ & $(0.213)$ & $(0.209)$ & $(0.265)$ & $(0.215)$ \\
\hline \multirow{2}{*}{ NPL/Loans } & -0.0781 & $0.230^{* *}$ & 0.268 & -0.0122 & $0.395^{* * *}$ & $0.385^{* * *}$ & $0.436^{* * *}$ & $0.382^{* * *}$ \\
\hline & $(0.126)$ & $(0.110)$ & $(0.178)$ & $(0.112)$ & $(0.080)$ & $(0.079)$ & $(0.092)$ & $(0.080)$ \\
\hline \multirow{2}{*}{ Log Assets } & $-2.690^{*}$ & -0.819 & $-4.334^{* * *}$ & $-2.749^{*}$ & $-4.751^{* * *}$ & $-5.378^{* * * *}$ & $-4.471^{* * * *}$ & $-4.632^{* * *}$ \\
\hline & (1.548) & $(1.507)$ & $(1.335)$ & $(1.455)$ & $(0.646)$ & $(0.579)$ & $(0.733)$ & $(0.624)$ \\
\hline
\end{tabular}


Table 5. Continued

\begin{tabular}{|c|c|c|c|c|c|c|c|c|}
\hline & (1) & (2) & (3) & (4) & (5) & (6) & (7) & (8) \\
\hline \multirow{2}{*}{ Government Owned } & $-152.0^{* *}$ & & & & 0.0212 & & & \\
\hline & $(77.23)$ & & & & (3.047) & & & \\
\hline \multirow{2}{*}{ Foreign Owned } & & $-260.1^{* * *}$ & & & & -1.642 & & \\
\hline & & $(62.25)$ & & & & $(3.088)$ & & \\
\hline \multirow{2}{*}{ Listed } & & & $436.5^{*}$ & & & & $16.30^{* * * *}$ & \\
\hline & & & (255.8) & & & & (3.825) & \\
\hline \multirow{2}{*}{ Recapitalised } & & & & $-159.1^{* *}$ & & & & 5.567 \\
\hline & & & & (76.70) & & & & $(3.622)$ \\
\hline \multirow{2}{*}{ GDP Growth } & -0.0951 & -0.199 & 0.0227 & -0.153 & 0.0922 & 0.126 & 0.0914 & 0.0952 \\
\hline & $(0.231)$ & $(0.227)$ & $(0.480)$ & $(0.233)$ & $(0.198)$ & $(0.196)$ & $(0.229)$ & $(0.199)$ \\
\hline \multirow{2}{*}{ GDP Per Capita } & 0.001 & 0.000 & 0.000 & 0.001 & $0.001^{* *}$ & $0.001^{* * *}$ & 0.001 & $0.001^{* *}$ \\
\hline & $(0.000)$ & $(0.000)$ & $(0.001)$ & $(0.000)$ & $(0.000)$ & $(0.000)$ & $(0.000)$ & $(0.000)$ \\
\hline \multirow{2}{*}{ Country Dummy } & $2.707^{*}$ & $3.006^{* *}$ & 1.107 & $3.090^{*}$ & 0.579 & $1.179^{*}$ & -0.381 & 0.511 \\
\hline & $(1.605)$ & $(1.512)$ & (1.618) & $(1.711)$ & $(0.726)$ & $(0.697)$ & $(0.859)$ & $(0.726)$ \\
\hline \multirow{2}{*}{ Year } & $2.827^{* * *}$ & $2.787^{* * *}$ & 0.765 & $3.015^{* * *}$ & $2.011^{* * *}$ & $1.851^{* * *}$ & $1.575^{* * *}$ & $1.941^{* * *}$ \\
\hline & $(0.547)$ & $(0.492)$ & $(0.945)$ & $(0.575)$ & $(0.321)$ & $(0.345)$ & $(0.383)$ & $(0.325)$ \\
\hline \multirow{2}{*}{ Constant } & $-5,408^{* * *}$ & $-5,333^{* * *}$ & $-1,901$ & $-5,790^{* * * *}$ & $-3,955^{* * *}$ & $-3,621^{* * *}$ & $-3,095^{* * *}$ & $-3,816^{* * * *}$ \\
\hline & $(1,053)$ & $(955.7)$ & $(1,746)$ & $(1,113)$ & (639.7) & $(689.7)$ & (763.7) & $(648.5)$ \\
\hline Observations & 513 & 513 & 513 & 513 & 443 & 443 & 443 & 443 \\
\hline Banks & 117 & 117 & 117 & 117 & 102 & 102 & 102 & 102 \\
\hline Goodness of Fit & 0.297 & 0.252 & 0.137 & 0.139 & 0.387 & 0.390 & 0.301 & 0.380 \\
\hline Wald chi (2) & $69.94^{* * * *}$ & $82.43^{* * * *}$ & $41.43^{* * * *}$ & $65.37^{* * * * *}$ & $0.292 .32^{* * *}$ & $270.78^{* * * *}$ & $223.80^{* * * *}$ & $269.84^{* * * *}$ \\
\hline
\end{tabular}

Standard errors in parentheses and ${ }^{* * * *} \mathrm{p}<0.01,{ }^{* * *} \mathrm{p}<0.05,{ }^{*} \mathrm{p}<0.1$

(c) Korea Institute for International Economic Policy 
Table 6. Risk Management and Market Discipline

\begin{tabular}{|c|c|c|c|}
\hline & (1) & (2) & (3) \\
\hline \multirow{2}{*}{ Information } & $-22.52^{* * *}$ & $-21.81^{* * *}$ & $-22.99^{* * *}$ \\
\hline & $(4.717)$ & $(4.201)$ & $(4.637)$ \\
\hline \multirow{2}{*}{ Information * NPL } & $1.112^{* * *}$ & $1.095^{* * *}$ & $1.133^{* * *}$ \\
\hline & $(0.178)$ & $(0.163)$ & $(0.178)$ \\
\hline \multirow{2}{*}{ CR4 } & & $0.429^{*}$ & \\
\hline & & $(0.243)$ & \\
\hline \multirow{2}{*}{ HHI } & & & 14.16 \\
\hline & & & $(28.69)$ \\
\hline \multirow{2}{*}{ ROA } & 0.0418 & 0.0692 & 0.0413 \\
\hline & $(0.305)$ & $(0.292)$ & $(0.308)$ \\
\hline \multirow{2}{*}{ NPL/Loans } & $-14.40^{* * * *}$ & $-14.21^{* * *}$ & $-14.68^{* * *}$ \\
\hline & $(2.326)$ & $(2.130)$ & $(2.329)$ \\
\hline \multirow{2}{*}{ Log Assets } & $-4.113^{* *}$ & $-3.428^{* *}$ & $-3.661^{* *}$ \\
\hline & $(1.780)$ & $(1.726)$ & $(1.735)$ \\
\hline \multirow{2}{*}{ Government Owned } & 5.949 & 5.212 & 5.119 \\
\hline & $(8.869)$ & $(8.163)$ & $(8.333)$ \\
\hline \multirow{2}{*}{ Foreign Owned } & $18.61^{* * *}$ & $18.41^{* * *}$ & $18.80^{* *}$ \\
\hline & $(8.444)$ & $(7.751)$ & $(7.946)$ \\
\hline \multirow{2}{*}{ Listed } & $15.03^{*}$ & 11.54 & $14.36^{* *}$ \\
\hline & $(7.713)$ & $(7.021)$ & $(7.321)$ \\
\hline \multirow{2}{*}{ Recapitalised } & 7.742 & 6.976 & 7.522 \\
\hline & $(10.42)$ & $(9.568)$ & (9.769) \\
\hline \multirow{2}{*}{ GDP Growth } & -0.190 & -0.331 & -0.218 \\
\hline & $(0.205)$ & $(0.224)$ & $(0.217)$ \\
\hline \multirow{2}{*}{ GDP Per Capita } & 0.000 & 0.000 & 0.000 \\
\hline & $(0.000)$ & $(0.000)$ & $(0.000)$ \\
\hline \multirow{2}{*}{ Country Dummy } & 0.152 & 1.482 & 0.396 \\
\hline & $(2.233)$ & $(2.205)$ & $(2.229)$ \\
\hline \multirow{2}{*}{ Year } & $2.557^{* * *}$ & $2.644^{* * *}$ & $2.613^{* * *}$ \\
\hline & $(0.441)$ & $(0.440)$ & $(0.462)$ \\
\hline \multirow{2}{*}{ Constant } & $-4,757^{* * *}$ & $-4,978^{* * *}$ & $-4,872^{* * *}$ \\
\hline & $(854.0)$ & $(860.1)$ & (899.2) \\
\hline Observations & 513 & 513 & 513 \\
\hline Banks & 117 & 117 & 117 \\
\hline Goodness of Fit & 0.187 & 0.191 & 0.183 \\
\hline Wald chi (2) & $116.99^{* * * *}$ & $125.01^{* * * *}$ & $114.2^{* * * *}$ \\
\hline
\end{tabular}

Standard errors in parentheses and ${ }^{* * *} \mathrm{p}<0.01,{ }^{* *} \mathrm{p}<0.05,{ }^{*} \mathrm{p}<0.1$ 


\section{CONCLUSIONS}

This paper analyses the effectiveness of market discipline in enhancing prudential risk management practices among the East Asian banks. More specifically, it studies the role of information disclosure and interbank deposits in influencing banks' management of capital ratio. A sample of 122 banks from five countries (Indonesia, Korea, Malaysia, Philippines and Thailand) is analyzed over the period from 1995 to 2005. This is a crucial period for the East Asian banking system during which the financial crisis happened and major financial restructuring were initiated. The present study aims to identify the effect of these changes on the market discipline mechanism. From an emerging market perspective, the findings of this study will enable us to answer a very pertinent question as to whether greater market concentration discourages prudential risk management practices. This is a very pertinent question that we need to address in the context of the East Asian banking system given the fact that major consolidation has taken place in the sector after the Asian financial crisis. In addition, this study also aims to identify how the ownership structure of the banks influences market discipline.

We find evidence of market discipline operating through interbank deposits but not through disclosure. However, we find that greater market concentration reduces banks' incentive to hold capital and improves the effectiveness of information disclosure as market discipline tool. Prior to the crisis, banks in East Asia lacked transparency (MacDonald, 1998) and some of the information that were disclosed did not reflect the actual risk that the banks were exposed to (Rosengren, 1999). Regulators in East Asia took steps to improve financial disclosure after the crisis by adopting International Accounting Standards and mandating greater and more frequent disclosure requirement (OECD, 2003). This may be the reason why disclosure becomes an effective market discipline tool as the banks become more concentrated. Similar to Wu and Bowe (2010), we find that interbank deposits fail to become an effective market discipline tool when the market becomes more concentrated. This suggests that lack of competition in the banking sector reduces the effectiveness of interbank deposits as a market discipline tool.

When the ownership structure of the banks is taken into account, we find that government owned banks, foreign banks and recapitalized banks are subject to market disciplining effect when disclosure is taken into account. But, this is not the case when interbank deposits are considered. In addition, we find that greater 
disclosure and interbank funding induce listed banks to hold lower capital. This suggests that listed banks in East Asia are not subjected to market disciplining effect. Similarly, Wu and Bowe (2010) also find that listed banks in China are not sensitive to market disciplining effect. Finally, we find that banks with poor loan quality hold lower capital, but for a given quality of loans, banks that disclose more risk related information hold more capital. This suggests that disclosure encourages banks with low quality loans to be more prudent.

The empirical evidence presented in this paper confirms the effectiveness of market discipline in the East Asian banking system. Greater concentration in the banking increases the effectiveness of disclosure as market disciplining tool. As a result, regulators need to ensure that the disclosure requirements of the banks are further enhanced so that banks disclose pertinent information to general public on timely manner. This puts the banks under greater scrutiny and can help in elevating the moral hazard problem associated with big players in the banking sector.

\section{Appendix}

Bank level disclosure index is constructed using the information obtained from BankScope database. The indices estimate the level of information that banks provide in their published financial statements on fifteen disclosure items. These indices show whether banks disclose information relating different type of risk that they face such as interest rate risk, credit risk, liquidity risk, market risk and solvency risk. The composite index is defined as

$$
\text { DISC }=\frac{1}{17} \sum_{i=1}^{15} S_{i}
$$

where each sub-index $S_{i}$, can be related to one or more sources of risk. The definition and the ordering of the fifteen sub-indices are based on the presentation in the BankScope database. The list of sub-indices used in the study is included in more detail below. A value of 0 is given for each of the sub-indices when there is no entry in any of the corresponding categories and a value of 1 otherwise. However, for the capital sub-index we assign a value of 0 when there is no entry in any of the four categories, 1 if there is only one entry, 2 if there are two entries 
and 3 if there are three or four entries. Note that whenever a bank discloses information on three of these items, one can infer the fourth. As such, providing information on three items is therefore considered same as providing information on four items. This causes the maximum attainable score on the sum of the subindices to be 17 .

Table 7. Disclosure Index

\begin{tabular}{|c|c|c|c|}
\hline & Sub-index & Categories & Basel Risk Category \\
\hline \multicolumn{4}{|l|}{ ASSETS } \\
\hline \multirow{4}{*}{ Loans } & $S_{1}$ : Loans by Maturity & $\begin{array}{l}\text { Short-term loan }(<1 \text { year }), \\
\text { Medium-term loan }(<3 \text { years }) \\
\& \text { Long-term loan }(>3 \text { years })\end{array}$ & $\begin{array}{l}\text { Interest Rate Risk, } \\
\text { Liquidity Risk }\end{array}$ \\
\hline & $\mathrm{S}_{2}$ : Loan by Type & $\begin{array}{l}\text { Mortgage Loan, Retail Loan, } \\
\text { Commercial Loans, } \\
\text { Loans to Banks and } \\
\text { Other Loans }\end{array}$ & Credit Risk \\
\hline & $\mathrm{S}_{3}$ : Problem Loans & Total Impaired Loans & Credit Risk \\
\hline & $\mathrm{S}_{4}$ : Problem Loans by Type & $\begin{array}{l}\text { Normal Loan, Special Mention } \\
\text { Loan, Substandard Loan, } \\
\text { Doubtful Loans and } \\
\text { Restructured Loan }\end{array}$ & Credit Risk \\
\hline \multirow{3}{*}{$\begin{array}{l}\text { Other Earning } \\
\text { Assets }\end{array}$} & S5: Investments by Type & $\begin{array}{l}\text { Loans and Advances to Banks } \\
\text { Reverse Repos and Cash } \\
\text { Collateral Securities, } \\
\text { Investments in Property and } \\
\text { Other Earning Assets }\end{array}$ & Liquidity Risk \\
\hline & S6: Securities by Type & $\begin{array}{l}\text { Trading Securities, Derivatives, } \\
\text { Government Securities, } \\
\text { Equity Investments, Other }\end{array}$ & Liquidity Risk \\
\hline & S$_{7}$ : Investments by Maturity & $\begin{array}{l}\text { Debt Securities, Senior Debt, } \\
\text { Subordinated Debts, } \\
\text { ( }<3 \text { months, } 3 \text { to } 12 \text { months, } \\
1 \text { to } 5 \text { years } \&>5 \text { years) }\end{array}$ & Liquidity Risk \\
\hline \multicolumn{4}{|l|}{ LIABILITIES } \\
\hline \multirow{3}{*}{ Deposits } & S$_{8}$ : Deposits by Maturity & $\begin{array}{l}\text { Retail and Other deposit } \\
(<3 \text { months, } 3 \text { to } 12 \text { months, } \\
1 \text { to } 5 \text { years } \&>5 \text { years })\end{array}$ & $\begin{array}{l}\text { Interest rate Risk, } \\
\text { Liquidity Risk }\end{array}$ \\
\hline & S9: Deposits by Type & $\begin{array}{l}\text { Customer Deposit, Bank } \\
\text { Deposit, Government / } \\
\text { Municipalities Deposit }\end{array}$ & Liquidity Risk \\
\hline & $\mathrm{S}_{10}$ : Long-term Funding & $\begin{array}{l}\text { Senior Debt, Subordinated } \\
\text { Borrowing, Other Funding }\end{array}$ & $\begin{array}{l}\text { Liquidity Risk, } \\
\text { Market Risk }\end{array}$ \\
\hline
\end{tabular}

(c) Korea Institute for International Economic Policy 
Table 7. Continued

\begin{tabular}{|c|c|c|c|}
\hline & Sub-index & Categories & Basel Risk Category \\
\hline \multirow{3}{*}{ Memo Lines } & $\mathrm{S}_{11}$ : Reserves & Loan Loss Reserve & Credit Risk \\
\hline & $\mathrm{S}_{12}$ : Capital & $\begin{array}{l}\text { Total Capital Ratio, Tier } 1 \text { Ratio, } \\
\text { Total Capital, Tier } 1 \text { Capital }\end{array}$ & Cushion for Risk \\
\hline & $S_{13}$ Off-balance Sheet Items & $\begin{array}{l}\text { Letter of Credit Issued, } \\
\text { Bank Guarantee Letter, } \\
\text { Total Contingent Liabilities }\end{array}$ & Credit Risk \\
\hline \multicolumn{4}{|c|}{ INCOME STATEMENTS } \\
\hline & $S_{14}:$ Non-interest Income & $\begin{array}{l}\text { Net Fees \& Commission } \\
\text { Income, Net Gain }\end{array}$ & Market Risk \\
\hline & $\mathrm{S}_{15}$ : Loan Loss Provisions & Loan Loss Provisions & Credit Risk \\
\hline
\end{tabular}

\section{REFERENCES}

Aggarwal, R. and K. T. Jacques. 1998. "Assessing the Impact of Prompt Corrective Action on Bank Capital and Risk," Federal Reserve Bank of New York Economic Policy Review, vol. 4, no. 3, pp. 23-32.

Arena, M. 2008. "Bank Failures and Bank Fundamentals: A Comparative Analysis of Latin America and East Asia during the Nineties Using Bank-Level Data," Journal of Banking and Finance, vol. 32, no. 2, pp. 299-310.

Asarkaya, Y. and S. Ozcan. 2007. "Determinants of Capital Structure in Financial Institutions: The Case of Turkey," Journal of BRSA Banking and Financial Markets, vol. 1, no. 1, pp. 91-109.

Ayuso, J., Pérez, D. and J. Saurina. 2004. "Are Capital Buffers pro-Cyclical? Evidence from Spanish Panel Data,” Journal of Financial Intermediation, vol. 13, no. 2, pp. 249-264.

Baer, H. and E. Brewer. 1986. "Uninsured Deposits as a Source of Market Discipline: Some New Evidence,” Economic Perspectives, vol. 10, no. 5, pp. 23-31.

Barth, J. R., Caprio, G. and R. Levine. 2004. "Bank Regulation and Supervision: What Works Best?," Journal of Financial Intermediation, vol. 13, no. 2, pp. 205-248.

Berger, A. N. 1991. "Market Discipline in Banking," In Proceedings from Conference on Bank Structure and Competition. Federal Reserve Bank of Chicago. pp. 419-437.

Bliss, R. R. 2004. Market Discipline: Players, Processes, and Purposes. In Hunter, W., Kaufman G., Borio, C. and K. Tsatsaronis. (eds.) Market Discipline Across Countries and Industires. Boston: MIT Press.

Bliss, R. R. and M. J. Flannery. 2002. "Market Discipline in the Governance of US Bank Holding Companies: Monitoring vs. Influencing," European Finance Review, vol. 6, no. 3, pp. 361-395. 
Blum, J. M. 2002. “Subordinated Debt, Market Discipline, and Bank’s Risk Taking,” Journal of Banking and Finance, vol. 26, no. 7, pp. 1427-1441.

Boot, A. W. and A. Schmeits. 2000. "Market Discipline and Incentive Problems in Conglomerate Firms with Applications to Banking," Journal of Financial Intermediation, vol. 9, no. 3, pp. 240-273.

Borio, C., Furfine, C. and P. Lowe. 2001. Procyclicality of the Financial System and Financial Stability: Issues and Policy Options. In Marrying the Macro- and Micro- Prudential Dimensions of Financial Stability. BIS Papers, no. 1, pp. 1-57.

Calomiris, C. W. and J. R. Mason. 1997. "Contagion and Bank Failures During the Great Depression: The June 1932 Chicago Banking Panic," American Economic Review, vol. 87, no. 5, pp. 863-883.

Cook, D. O. and L. J. Spellman. 1994. "Repudiation Risk and Restitution Costs : Toward Understanding Premiums on Insured Deposits," Journal of Money, Credit and Banking, vol. 26. no. 3, part 1, pp. 439-459.

Cordella, T. and E. Levy Yeyati. 1998. "Public Disclosure and Bank Failures," IMF Staff Papers, vol, 45, no. 1, pp. 110-131

De Nicoló, G., Jalal, A. M. and J. H. Boyd. 2006. Bank Risk-Taking and Competition Revisited: New Theory and New Evidence. IMF Working Papers, no. 06-297.

Diamond, D. W. and P. H. Dybvig. 1986. "Banking Theory, Deposit Insurance, and Bank Regulation," Journal of Business, vol. 59, no. 1, pp. 55-68.

Diamond, D. W. and R. G. Rajan. 2000. "A Theory of Bank Capital," Journal of Finance, vol. 55, no. 6, pp. 2431-2465.

Ellis, D. M. and M. J. Flannery. 1992. "Does the Debt Market Assess Large Banks, Risk?: Time Series Evidence from Money Center CDs," Journal of Monetary Economics, vol. 30, no. 3, pp. 481-502.

Flannery, M. J. 1994. "Debt Maturity and the Deadweight Cost of Leverage: Optimally Financing Banking Firms," American Economic Review, vol. 84, no. 1, pp. 320- 331.

.2001. "The Faces of Market Discipline," Journal of Financial Services Research, vol. 20, no. 2, pp. 107-119.

Flannery, M. J. and K. P. Rangan. 2008. "What Caused the Bank Capital Build-up of the 1990s?," Review of Finance, vol. 12, no. 2, pp. 391-429.

Fonseca, A. R. and F. Gonzalez. 2010. "How Bank Capital Buffers Vary across Countries: The Influence of Cost of Deposits, Market Power and Bank Regulation," Journal of Banking and Finance, vol. 34, no. 4, pp. 892-902.

Gambacorta, L. and P. E. Mistrulli. 2004. "Does Bank Capital Affect Lending Behavior?," Journal of Financial Intermediation, vol. 13, no. 4, pp. 436-457.

Goldberg, L. G. and S. C. Hudgins. 1996. "Response of Uninsured Depositors to Impending S\&L Failures: Evidence of Depositor Discipline," Quarterly Review of Economics and Finance, vol. 36, no. 3, pp. 311-325.

2002. "Depositor Discipline and Changing Strategies for Regulating Thrift Institutions," Journal of Financial Economics, vol. 63, no. 2, pp. 263-274.

Greenspan, A. 2001. The Financial Safety Net. In Remarks to the 37th Annual Conference on Bank Structure and Competition. Chicago, IL: Federal Reserve Bank of Chicago. 
Gropp, R. and F. Heider. 2009. What Can Corporate Finance Say about Banks' Capital Structures. European Central Bank Working Paper, no. 1096.

Gropp, R. and J. Vesala. 2004. "Deposit Insurance, Moral Hazard and Market Monitoring," Review of Finance, vol. 8, no. 4, pp. 571-602.

Hamalainen, P., Hall, M. and B. Howcroft. 2001. A Framework for Implementing Market Discipline in Financial Regulatory Design. Loughborough University Banking Centre. . 2003. Market Discipline: A Theoretical Framework for Regulatory Policy Development. In Kaufman G. (eds.) Market Discipline in Banking: Theory and Evidence. United Kingdom: Emerald. pp. 57-97.

Hamid, F. S. 2013. "The Effect of Reliance on International Funding on Banking Fragility: Evidence from East Asia," Margin: The Journal of Applied Economic Research, vol. 7, no. 1 , pp. 29-60. 2014. "Information Disclosure and Depositor Discipline : Evidence Based on the East Asian Crisis," Journal of Asian Development Studies, vol. 3, no. 2, pp. 16-40.

Hassan, O. and C. Marston. 2010. Disclosure Measurement in the Empirical Accounting Literature: A Review Article. London: Brunel University Uxbridge.

Hoang, K. TA., Faff, R. and M. Haq. 2014. "Market Discipline and Bank Risk Taking," Australian Journal of Management, vol. 39, no. 3, pp. 327-350.

Hosono, K., Iwaki, H. and K. Tsuru. 2005. Banking Crises, Deposit Insurance, and Market Discipline: Lessons from the Asian Crises. RIETI Discussion Paper Series, no. 05-E-029.

Ito, T. and Y. Hashimoto. 2007. Bank Restructuring in Asia: Crisis Management in the Aftermath of the Asian Financial Crisis and Prospects for Crisis Prevention- Malaysia. RIETI Discussion Paper Series, no. 07-E-039.

Jacques, K. and P. Nigro. 1997. "Risk-Based Capital, Portfolio Risk, and Bank Capital: A Simultaneous Equations Approach,” Journal of Economics and Business, vol. 49, no. 6, pp. 533-547.

Jokipii, T. and A. Milne. 2008. "The Cyclical Behaviour of European Bank Capital Buffers," Journal of Banking and Finance, vol. 32, no. 8, pp. 1440-1451.

Kim, D. and A. M . Santomero. 1998. "Risk in Banking and Capital Regulation," Journal of Finance, vol. 43, no. 5, pp. 1219-1233.

Kleff, V. and M. Weber. 2008. "How Do Banks Determine Capital? Evidence from Germany," German Economic Review, vol. 9, no. 3, pp. 354-372.

La Porta, R., Lopez-de-Silanes, F. and A. Shleifer. 2002. "Government Ownership of Banks," Journal of Finance, vol. 57, no. 1, pp. 265-301.

Laeven, L. 1999. Risk and Efficiency in East Asian Banks. World Bank Policy Research Working Paper, no. 2255.

Laeven, L. and R. Levine. 2009. "Bank Governance, Regulation, and Risk Taking," Journal of Financial Economics, vol. 93, no. 2, pp. 259-275.

MacDonald, S. B. 1998. “Transparency in Thailand's 1997 Economic Crisis: The Significance of Disclosure," Asian Survey, vol. 38, no. 7, pp. 688-702.

Marston, C. L. and P. J. Shrives. 1991. "The Use of Disclosure Indices in Accounting Research: A Review Article," British Accounting Review, vol. 23, no. 3, pp. 195-210. 
Martinez Peria, M. S. and S. L. Schmukler. 1999. Do Depositors Punish Banks for 'Bad' Behavior?: Market Discipline in Argentina, Chile, and Mexico. World Bank Policy Research Paper, no. 2058.

Micco, A., Panizza, U. and M. Yanez. 2007. "Bank Ownership and Performance. Does Politics Matter?," Journal of Banking and Finance, vol. 31, no. 1, pp. 219-241.

Nier, E. and U. Baumann. 2006. "Market Discipline, Disclosure and Moral Hazard in Banking," Journal of Financial Intermediation, vol. 15, no. 3, pp. 332-361.

OECD. 2003. White Paper on Corporate Governance in Asia. OECD Publishing.

Rosengren, E. 1999. Will Greater Disclosure and Transparency Prevent the next Banking Crisis? In Hunter, W. C., Kaufman, G. G. and T. H. Krueger. (eds.) The Asian Financial Crisis: Origins, Implications, and Solutions, New York: Springer. pp. 369-376.

Sironi, A. 2001. "Testing for Market Discipline in the European Banking Industry: Evidence from Subordinated Debt," Journal of Money, Credit and Banking, vol. 35, no. 3, pp. 443472.

Stolz, S. and M. Wedow. 2011. "Banks' Regulatory Capital Buffer and the Business Cycle: Evidence for German Savings and Cooperative Banks," Journal of Financial Stability, vol. 7, no. 2, pp. 98-110.

Tabak, B. M., Noronha, A. C. and D. Cajueiro. 2011. "Bank Capital Buffers, Lending Growth and Economic Cycle: Empirical Evidence for Brazil," In 2nd BIS CCA Conference on Monetary Policy, Financial Stability and the Business Cycle.

Tadesse, S. 2006. "The Economic Value of Regulated Disclosure: Evidence from the Banking Sector," Journal of Accounting and Public Policy, vol. 25, no. 1, pp. 32-70.

Williams, J. and N. Nguyen. 2005. "Financial Liberalisation, Crisis, and Restructuring: A Comparative Study of Bank Performance and Bank Governance in South East Asia," Journal of Banking and Finance, vol. 29, no. 8-9, pp. 2119-2154.

$\mathrm{Wu}, \mathrm{Y}$. and M. Bowe. 2010. "Information Disclosure, Market Discipline and the Management of Bank Capital: Evidence from the Chinese Financial Sector," Journal of Financial Services Research, vol. 38, no. 2, pp. 159-186.

First version received on 19 January 2017

Peer-reviewed version received on 10 March 2017

Final version accepted on 21 March 2017

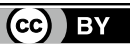

(C) 2017 EAER articles are distributed under the terms of the Creative Commons Attribution 4.0 International License (http://creativecommons.org/licenses/by/4.0/), which permits unrestricted use, distribution, and reproduction in any medium, provided you give appropriate credit to the original author(s) and the source, provide a link to the Creative Commons license. 